\title{
Pengaruh Metode Inkuiri terhadap Hasil Belajar Ilmu Pengetahuan Alam Siswa Kelas V di SD Negeri 3 Dompu Tahun Pembelajaran 2020/2021
}

\author{
Hidayat \\ STKIP Yapis Dompu \\ *Coresponding Author : hidayatibnuabidin@gmail.com \\ Dikirim: 29-08-2021 ; Direvisi: 30-08-2021 ; Diterima: 30-08-2021
}

\begin{abstract}
Abstrak: Metode inkuiri merupakan suatu proses mental yang lebih tinggi tingkatannya. Hasil pembelajaran adalah hasil yang dicapai setelah diberikan tes hasil belajar pada setiap akhir pembelajaran. Masalah yang dijawab dalam penelitian ini adalah Apakah ada pengaruh penggunaan metode inkuiri terhadap peningkatan hasil belajar Ilmu Pengetahuan Alam tentang Tumbuhan Hijau siswa kelas V SD Negeri 3 Dompu tahun pembelajaran 2020/2021. Jenis penelitian yang digunakan dalam penelitian ini adalah kuantitatif. Yang menjadi populasi dalam penelitian ini yaitu siswa kelas V sebanyak 54 orang siswa sehingga penelitian ini adalah penelitian populasi. Metode pengumpulan data yang digunakan yaitu, angket dan tes. Teknik analisis data yang digunakan dalam penelitian ini adalah dengan menggunakan rumus regresi linier sederhana. Berdasarkan hasil analisis data bahwa metode inkuiri tidak berpengaruh secara signifikan dengan $\mathrm{R}^{2}=0,011 \times 100 \%=1,1 \%$ terhadap hasil belajar siswa dan yang paling besar signifikan besarnya adalah sebanyak 99,9\% oleh faktor lain. Dengan hasil persamaan regresinya adalah, $Y=$ $2.615+1.167 x$. Maknanya jika variabel $\mathrm{X}$ adalah 0 maka nilai variabel $\mathrm{Y}$ adalah 2.615 dan jika variabel $\mathrm{X}$ di naikkan satu satuan maka variabel $\mathrm{Y}$ akan menjadi 1.167. Sehingga dengan demikian tujuan (Ha) yang diajukan dalam penelitian ini yaitu ada pengaruh metode inkuiri terhadap hasil belajar Ilmu Pengetahuan Alam tentang Tumbuhan Hijau siswa Kelas V SD Negeri 3 Dompu tahun pembelajaran 2020/2021 tidak dapat diterima atau ditolak. Berarti hipotesis Nihil (Ho) diterima, artinya metode Inkuiri tidak dapat berpengaruh signifikan terhadap hasil belajar siswa pada materi Ilmu Pengetahuan Alam tentang tumbuhan hijau, karna banyak dipengaruhi oleh faktor lain.
\end{abstract}

Kata Kunci: Metode inkuiri; Hasil Belajar

Abstract: The inquiry method is a higher level mental process. Learning outcomes are the results achieved after being given a learning outcome test at the end of each lesson. The problem that is answered in this study is whether there is an effect of using the inquiry method on improving learning outcomes of Natural Science about Green Plants for fifth grade students of SD Negeri 3 Dompu in the 2020/2021 academic year. The type of research used in this research is quantitative. The population in this study were 54 students of class V, so this research is a population study. Data collection methods used are, questionnaires and tests. The data analysis technique used in this research is to use a simple linear regression formula. Based on the results of data analysis that the inquiry method has no significant effect with R2 $=0.011 \times 100 \%=1.1 \%$ on student learning outcomes and the most significant is $99.9 \%$ by other factors. With the results of the regression equation is, $\mathrm{Y}=2.615+1.167 \mathrm{x}$. This means that if the variable $\mathrm{X}$ is 0 then the value of the variable $\mathrm{Y}$ is 2,615 and if the variable $\mathrm{X}$ is increased by one unit then the variable $\mathrm{Y}$ will be 1.167 . Thus, the goal (Ha)

@ 2021 JagoMipa (https://bimaberilmu.com/jurnal/index.php/jagomipa) 
proposed in this study is that the influence of the inquiry method on learning outcomes of Natural Science about Green Plants for Class V SD Negeri 3 Dompu students in the 2020/2021 academic year cannot be accepted or rejected. It means that the null hypothesis (Ho) is accepted, meaning that the Inquiry method cannot have a significant effect on student learning outcomes in Natural Science material about green plants, because it is heavily influenced by other factors.

Keywords: Inquiry Methods, Learning Outcomes

\section{PENDAHULUAN}

Kata inkuiri sering juga dinamakan heuriskin yang berasal dari bahasa Yunani, yang memiliki arti saya menemukan. Metode Inkuiri berkaitan dengan aktivitas pencarian pengetahuan atau pemahaman untuk memuaskan rasa ingin tahu sehingga siswa akan menjadi pemikir kreatif yang mampu menyelesaikan masalah.Hal ini sejalan dengan pendapat Sanjaya (2006: 196) bahwa "Metode inkuiriadalah suatu metode pembelajaran yang menekankan pada proses berpikir secara kritis dan analitis untuk mencari dan menemukan sendiri jawaban dari suatu permasalahan yang dipertanyakan”.

Maka dapat diambil kesimpulan bahwa metode Inkuiriadalah metode yang memberi kesempatan kepada siswa untuk terlibat secara aktif dalam proses pembelajaran melalui percobaan maupun eksperimen sehingga melatih siswa berkreativitas dan berpikir kritis untuk menemukan sendiri suatu pengetahuan yang pada akhirnya mampu menggunakan pengetahuannya tersebut dalam menyelesaikan masalah yang dihadapi.

Menurut Dimyati dan Mudjiono (2009: 3). Hasil belajar merupakan tujuan akhir dilaksanakannya kegiatan pembelajaran disekolah. Hasil belajar dapat ditingkatkan melalui usaha sadar yang dilakukan secara sistematis mengarah kepada perubahan yang positif yang kemudian disebut dengan proses belajar. Akhir dari proses belajar adalah perolehan suatu hasil belajar siswa. Hasil belajar siswa dikelas terkumpul dalam himpunan hasil belajar kelas.Semua hasil belajar tersebut merupakan hasil dari suatu interaksi tindak belajar dan tindak mengajar. Dari sisi guru, tindak mengajar diakhiri dengan proses evaluasi hasil belajar, sedangkan dari sisi siswa, hasil belajar merupakan berakhirnya penggal dan puncak proses belajar.

Dari hasil observasi awal tanggal 7 September 2015 ditemukan bahwa adanya perilaku yang dapat menurunkan hasil belajar siswa seperti, sangat lamban dalam belajar, kurang motivasi dalam belajar, dan sering tidak masuk sekolah. Dengan demikian perlu adanya solusi dalam mengatasi rasa malas yang timbul dalam diri siswa.Dalam masalah ini peran guru sangat diperlukan, karena bagaimanapun guru sangat berperan penting dalam pendidikan dan sangat diharapkan kontribusinya dalam membantu siswa untuk mengatasi problem dalam belajar. Sebagaimana yang tertuang dalam kurikulum 2006 ( KTSP ) mata pelajaran IPA di SD/MI pembelajaran IPA sebaiknyadilaksanakan secarainkuiriilmiah (scientificinquiri) untuk menumbuhkan kemampuan berpikir, bekerja, dan bersikap ilmiah serta mengkomunikasikannya sebagai aspek penting kecakapan hidup. Oleh karena itu, pembelajaran IPA di SD menekankan pada pemberian pengalaman langsung melalui penggunaan dan pengembangan keterampilan proses dan sikap ilmiah, dalam hal ini seorang guru harus memiliki kompetensi yang cukup sebagai pengelola pembelajaran. Seorang guru yang memiliki kompetensi diharapkanakan lebih baik 
dan mampu menciptakan suasana dan lingkungan belajar yang efektif, sehingga hasil belajar siswa akan optimal.Sehubungan dengan hal di atas metode mengajar yang digunakan oleh guru hendaknya sedemikian rupa bervariasi sesuai dengan tujuan dan materi yang diajarkan.

Dari uraian di atas peneliti merasa tertarik. Ketertarikan untuk meneliti permasalahan ini yang dituangkan oleh peneliti dalam sebuah skipsi dengan judul:"Pengaruh metode inkuiri terhadap hasil belajar Ilmu Pengetahuan Alam siswa kelas V di SD Negeri 3 Dompu. Tahun pembelajaran 2020/2021”.

\section{KAJIN TEORI}

\section{Pengertian Metode Inkuiri}

Metode inkuiri merupakan metode discovery artinya suatu proses mental yang lebih tingkatannya. Upaya mengembangkan disiplin intelektual dan ketrampilan yang dibutuhkan siswa untuk membantu memecahkan masalah dengan memberikan pertanyaan-pertanyaan yang memperoleh jawaban atas dasar rasa ingin tahu merupakan bagian proses inkuiri.Keterlibatan aktif secara mental dalam kegiatan belajar yang sebenarnya.Inkuirisecara kooperatif memperkaya cara berpikir siswa dan mendorong mereka hakekat timbulnya pengetahuan tentative dan berusaha menghargai penjelasan (Anita, 2001:4).

\section{Tujuan Metode Inkuiri} berikut:

Beberapa tujuan dari metodeinkuiri dalam Permana 2000: 114) adalah sebagai

(1) Meningkatkan keterlibatan peserta didik dalam menemukan dan memproses bahan pelajarannya.

(2) Mengurangi ketergantungan siswa pada guru untuk mendapatkan pelajarannya

(3) Melatih peserta didik dalam menggali dan memanfaatkan lingkungan sebagai sumber belajar yang tidakada habisnya

(4) Memberi pengalaman belajar seumur hidup

a) Guru merangsang siswa dengan pertanyaan, masalah, permainan, dan tekateki.

b) Sebagai jawaban atas rangsangan yang diterimanya, siswa menentukan prosedur mencari dan mengumpulkan informasi atau data yang diperlukan untuk memecahkan pertanyaan, pernyataan, dan masalah.

c) Siswa menghayati pengetahuan yang diperolehnya dengan inkuiriyang baru dilaksanakan.

d) Siswa menganalisis metodeinkuiridan prosedur yang ditemukan untuk dijadikan metode umum yang dapat diterapkannya ke situasi lain.

\section{Manfaat Metode Inkuiri} berikut:

Manfaat dari penggunaan metode pembelajaran inkuiri dapat dilihat sebagai

\section{(1) Pengajaran berpusat pada diri siswa.}

Salah satu prinsip psikologi belajar menyatakan bahwa makin besar dan makin sering keterlibatan siswa dalam kegiatan makin besar baginya untuk mengalami proses belajar. Dalam proses belajar inkuiri, siswa tidak hanya belajar konsep dan prinsip, tetapi juga mengalami proses belajar tentang pengarahan diri, pengendalian diri, tanggung jawab dan komunikasi sosial secara terpadu. 
(a) Membantu siswa mengembangkan keterampilan kognitif secara mandiri.

(b) Menguatkan pemahaman tentang pengertian dan daya ingat.

(c) Membangkitkan rasa senang menyelidiki.

(d) Memperoleh pengalaman bagaimana caranya belajar.

(e) Menguatkan konsep diri dengan mengembangkan rasa percaya diri.

(f) Mendorong pertumbuhan keterampilan berpikir kritis.

(g) Meningkatkan kemampuan berpikir intuitif.

(h) Meningkatkan rasa ingin tahu.

(i) Meningkatkan penghargaan kepada siswa untuk lebih mandiri.

(j) Mengembangkan potensi diri secara optimal.

(2) Pengajaran inkuiri dapat membentuk self concept (konsep diri), sehingga terbuka terhadap pengalaman-pengalaman baru, lebih kreatif, berkeinginan untuk selalu mengambil kesempatan yang ada dan pada umumnya memiliki mental yang sehat.

(3) Tingkat pengharapan bertambah, yaitu ada kepercayaan diri serta ide tertentu bagaimana ia dapat menyelesaikan suatu tugas dengan caranya sendiri.

(4) Pengembangan bakat dan kecakapan individu, Lebih banyak kebebasan dalam proses belajar mengajar berarti makin besar kemungkinannya untuk mengembangkan kecakapan, kemampuan dan bakat-bakatnya.

(5) Dapat memberi waktu kepada siswa untuk menganalisa dan mengakomodasiinformasi. Belajar yang sesungguhnya yaitu jika pembelajar bereaksi dan bertindak terhadap informasi melalui proses mental.

\section{Ciri-ciri Metode Pembelajaran Inkuiri}

Pembelajaran inkuiri memiliki beberapa ciri-ciri yang bisa dipahami, diantaranya:

(1) Strategi inkuiri menekankan kepada aktivitas siswa secara maksimal untuk mencari dan menemukan. Artinya strategi inkuiri menempatkan siswa sebagai subjek belajar. Dalam proses pembelajaran, siswa tidak hanya berperan sebagai penerima pelajaran melalui penjelasan guru secara verbal, tetapi mereka berperan untuk menemukan sendiri inti dari materi pelajaran itu sendiri.

(2) Seluruh aktivitas yang dilakukan siswa diarahkan untuk mencari dan menemukan jawaban sendiri dari sesuatu yang dipertanyakan, sehingga diharapkan dapat menumbuhkan sikap percaya diri (self belief). Dengan demikian, strategi pembelajaran inkuiri menempatkan guru bukan sebagai sumber belajar, akan tetapi sebagai fasilitator dan motivator belajar siswa. Aktivitas pembelajaran biasanya dilakukan melalui proses tanya jawab antara guru dan siswa. Karena itu kemampuan guru dalam menggunakan teknik bertanya merupakan syarat utama dalam melakukan inkuiri.

(3) Tujuan dari penggunaan strategi pembelajaran inkuiri adalah mengembangkan kemampuan berpikir secara sistematis, logis, dan kritis, atau mengembangkan kemampuan intelektual sebagai bagian dari proses mental. Dengan demikian, dalam strategi pembelajaran inkuiri siswa tak hanya dituntut untuk menguasai materi pelajaran, akan tetapi bagaimana mereka dapat menggunakan potensi yang dimilikinya. Manusia yang hanya menguasai pelajaran belum tentu dapat mengembangkan kemampuan berpikir secara optimal. Sebaliknya, siswa akan dapat mengembangkan kemampuan berpikirnya manakala ia bisa menguasai materi pelajaran. Strategi pembelajaran inkuiri merupakan bentuk dari 
pendekatan pembelajaran yang berorientasi kepada siswa (student centered approach). Dikatakan demikian, sebab dalam strategi ini siswa memegang peran yang sangat dominan dalam proses pembelajaran.

\section{Langkah-Langkah Metode Inkuiri}

Menurut Piaget di dalam Ida (2005:55). menjelaskan Inkuiri sebagai teknik pengajaran mengandung arti bahwa dalam proses pembelajaran berlangsung pengajar harus dapat mendorong dan memberi kesempatan kepada siswa untuk lebih aktif dalam belajar. Adapun langkah-langkah pembelajarannya:

(a) Membina suasana yang responsif diantara siswa.

(b) Mengemukakan permasalahan untuk di inkuiri (ditemukan) melalui cerita, film, gambar, dan sebagianya. Kemudian mengajukan pertanyaan kearah mencari, merumuskan dan memperjelas permasalahan dari cerita dan gambar.

(c) Mengajukan pertanyaan-pertanyaan kepada siswa, pertanyaan yangdiajukan bersifat mencari atau mengajukan informasi atas data tentang masalah tersebut.

(d) Merumuskan hipotesis/ perkiraan yang merupakan jawaban dari peryataan tersebut. Perkiraan jawaban ini akan terlihat tidaknya setelah pengumpulan data dan pembuktian atas data. Siswa mencoba merumuskan hipotesis permasalahan tersebut. Guru membantu dengan pertanyaan-pertanyaan pancingan.

(e) Menguji hipotesis, guru mengajukan petanyaan yang bersifat meminta data untuk pembuktian hipotesis.

(f) Pengambilan kesimpulan perumusan kesimpulan ini dilakukan guru dan siswa. (Piaget dalam Ida, 2005: 55).

(g) Metode inkuiri adalah sebagai teknik pengajaran yang memberi kesempatan kepada siswa lebih aktif dalam belajar dengan langkah- langkah yang sistematis yaitu membina suasana yang responsif, mengemukakan permasalahan dan mengajukan pertanyaan, merumuskan hipotesis dan kemudian mengujinya dan yang terakhir pengambilan kesimpulan yang dilakukan oleh siswa dan guru.

\section{Pengertian Hasil belajar}

Hasil belajar merupakan tujuan akhir dilaksanakannya kegiatan pembelajaran disekolah. Hasil belajar dapat ditingkatkan melalui usaha sadar yang dilakukan secara sistematis mengarah kepada perubahan yang positif yang kemudian disebut dengan proses belajar. Akhir dari proses belajar adalah perolehan suatu hasil belajar siswa. Hasil belajar siswa dikelas terkumpul dalam himpunan hasil belajar kelas.Semua hasil belajartersebut merupakan hasil dari suatu interaksi tindak belajar dan tindak mengajar. Dari sisi guru, tindak mengajar diakhiri dengan proses evaluasi hasil belajar, sedangkan dari sisi siswa, hasil belajar merupakan berakhirnya penggal dan puncak proses belajar (Dimyati dan Mudjiono, 2009: 3).

\section{Pembelajaran Ilmu Pengetahuan Alam (IPA) di SD}

Ilmu Pengetahuan Alam (IPA) mempelajari alam semesta, benda-benda yang ada dipermukaan bumi, didalam perut bumi dan di luar angkasa, baik yang dapat diamati indera maupun yang tidak dapat diamati dengan indera.Menurut Fowler dalam Trianto (2010), IPA adalah pengetahuan yang sistematis dan dirumuskan yang berhubungan dengan gelaja-gejala kebendaan dan didasarkan terutama atas pengamatan dan dedukasi.Sedangkan Kardi dan Nur dalam Trianto (2010) mengatakan bahwa IPA atau ilmu alam adalah ilmu tentang dunia zat, baik makhluk hidup maupun benda mati yang diamati.Adapun menurut Wahana dalam Trianto 
(2010), IPA adalah suatu kumpulan pengetahuaan yang tersusun secara sistematis dan dalam penggunaannya secara umum terbatas pada gejala-gejala alam.

\section{METODE PENELITIAN}

\section{Jenis penelitian}

Jenis penelitian ini adalah pendekatan kuantitatif sebab penelitian biasanya digunakan untuk menguji suatu teori, untuk menyajikan suatu fakta atau dengan deskripsi statistik. Untuk menunjukan hubungan antara variabel dan ada pula yang bersifat mengembangkan konsep, mengembangkan pemahaman.

Penelitian kuantitatif adalah metode penelitian yang melandaskan pada filsafat positivisme, digunakan untuk meneliti pada populasi atau sampel tertentu, tehnik pengambilan sampel pada umumnya dilakukan secara tehnik sampling, pengumpulan data menggunakan instrumen penelitian, analisa data bersifat kuantitantif/statistik dengan tujuan untuk menguji hipotesis yang telah ditetapkan.

Dalam penelitian ini terdiri dari dua variabel yaitu Variabel $X$ metode Inkuirisebagai variabel bebas dan Variabel Y Hasil belajar siswa sebagai variabel terikat.Sifat dari penelitian ini adalah korelasional yaitu menentukan tingkat pengaruh antara kedua variabel (Arikunto, 2006: 140).

\section{Populasi dan Sampel Populasi}

Populasi adalah jumlah keseluruhan subyek penelitian (Arikunto, 2002: 108), maka populasi dari penelitian ini adalah seluruh siswa kelas Va dan VbSDNegeri3 Dompu tahun pembelajaran 2015/2016.Kelas Va dengan 11 siswa laki-laki dan 16 siswa perempuan sehingga berjumlah 27 orang siswa sedangkan Kelas Vb dengan 10 siswa laki-laki dan 16 siswa perempuan sehingga berjumlah 26 orang. Adapun jumlah keseluruhan siswa kelas $\mathrm{Va}$ dan $\mathrm{Vb}$ adalah 54 siswa.

\section{Sampel}

Sampel adalah sebagian atau wakil dari populasi yang diteliti ( Arikunto, 2006:117).Lebih lanjut dikemukakan bahwa apabila dalam pengambilan sampel yang jumlah subyeknya besar dapat diambil antara $10-15 \%$ atau $20-25 \%$ atau lebih.

Jumlah keseluruhan siswa kelas $\mathrm{Va}$ dan $\mathrm{Vb}$ SDNegeri3 Dompu Tahun Pembelajaran 2015/2016 yang berjumlah 54siswa, maka yang akan diambil sebagai sampel dalam penelitian ini seluruh siswa berjumlah 54 siswa. Sebagai sampel dari jumlah populasi sehingga penelitian ini adalah penelitian populasi.

\section{Teknik Pengumpulan Data}

Teknik pengumpulan data adalah cara yang digunaka. Untuk memperoleh data yang dibutuhkan dalam penelitian ini maka teknik pengumpulan data menggunakan metode/teknik sebagai berikut:

\section{Teknik Angket}

Menurut Arikunto (2002: 128), Angket/Kuesioner adalah sejumlah pertanyaan tertulis yang digunakan untuk memperoleh informasi dari responden dalam arti laporan tentang pribadinya atau hal-hal lain yang diketahuinya. Adapun angket yang digunakan untuk mencari variabel $\mathrm{X}$ yaitu metode inkuiri. 
Dalam teknik pengumpulan data dengan angket ini peneliti akan membagi beberapa pernyataan sesuai dengan variabel kepada siswa yang dijadikan sampel penelitian yaitu yang berjumlah 54 orang siswa.

Angket diberikan pada siswa setelah belajar dengan metode inkuiri pada mata pelajaran IPA materi tumbuhan hijau, kelas Va dan Vb di SD Negeri 3 Dompu tahun pembelajaran 2015/2016.

\section{TeknikTes}

Tes yang digunakan adalah mengukur kemampuan siswa dalam menjawab soal-soal mata pelajaran IPA secara tertulis.Tes ini digunakan untuk memperoleh gambaran seberapa besar hasil belajar siswa pada mata pelajaran IPA materi tumbuhan hijau pada siswa kelas V SD Negeri 3 Dompu.

\section{Instrumen Penelitian}

Instrumen penelitian adalah alat atau metode yang dipergunakan untuk memperoleh data penelitian (Arikunto, 2002:156).

\section{Instrumen data Angket/ kuesioner}

Instrumen yang digunakan yaitu berupa pertanyaan-pertanyaan kepada responden yang telah disediakan berupa lembar angket/ kuesioner, yang telah disediakan jawaban sehingga responden tinggal memilih.Angket ini memuat 15 pertanyaan mengenai metode inkuiri dalam belajar masing-masing item pada angket tersedia empat alternatif jawaban ( $a, b, c$, dan d ) yang akan dipilih responden sesuai dengan pendapat mereka. Adapun cara pemberian skor untuk pilihan A diberi skor 4, pilih B diberi skor 3, C diberi skor 2 dan D diberi skor 1. Adapun indikator angket terlampir.Pada lampiran IV halaman 60.

\section{Instrument data Tes}

Instrumen tes digunakan untuk mengetahui apakah hasil belajar siswa pada mata pelajaran IPA materi tumbuhan hijau kelas $\mathrm{V}$ memiliki peningkatan atau tidak, dalam penelitian ini jumlah soal tes adalah terdiri dari 20 nomor untuk soal pilihan ganda dengan bobot pada setiap jawaban yang benar adalah 5 dan jawaban yang salah diberi bobot nol (0) sehingga skor maksimal untuk soal pilihan ganda yaitu 100.Adapun tes terlampir pada lampiran III halaman 58.

\section{Teknik Analisis Data}

Analisis Regresi Linear Sederhana dengan menggunakan SPSS 16. 0 adalah Metode Statistik yang berfungsi untuk menguji sejauh mana hubungan sebab akibat antara Variabel Faktor Penyebab (X) terhadap Variabel Akibatnya.Faktor Penyebab pada umumnya dilambangkan dengan $X$ atau disebut juga dengan Predictor sedangkan Variabel Akibat dilambangkan dengan $\mathrm{Y}$ atau disebut juga dengan Response.Regresi Linear Sederhana atau sering disingkat dengan SLR (Simple Linear Regression) juga merupakan salah satu Metode Statistik yang dipergunakan dalam produksi untuk melakukan peramalan ataupun prediksi tentang karakteristik kualitas maupun Kuantitas.

\section{HASIL DAN PEMBAHASAN}

Penelitian ini dilaksanakan di SD Negeri 3 Dompu mulai dari Selasa,9 September sampai dengan 9 November 2015 dengan data siswa sampel sebagai berikut: 
Tabel 1. Data Siswa Sebagai Sampel

\begin{tabular}{|l|l|l|l|l|}
\hline \multirow{2}{*}{ No } & \multirow{2}{*}{ Kelas } & \multicolumn{2}{|l|}{ Jenis kelamin } & \multirow{2}{*}{ Jumlah } \\
\cline { 3 - 5 } & & Laki-Laki & Perempuan & \\
\hline 1 & $\mathrm{Va}$ & 13 & 14 & 27 \\
\hline 2 & $\mathrm{Vb}$ & 14 & 13 & 27 \\
\hline \multicolumn{2}{|l|}{ Jumlah } & & & 54 \\
\hline
\end{tabular}

\section{Hasil Perhitungan Metode Inkuiri}

Sebelum melakukan penelitian terlebih dahulu menghubungi guru IPA kelas $\mathrm{Va}$ dan $\mathrm{Vb}$ untuk mengetahui jadwal mata pelajaran IPA.Untuk jadwal mata pelajaran IPA di kelas Vayaitu pada hari rabu pukul. 09.30 WITA dan hari kamis pukul. 09.30.kelas Vb yaitu pada hari rabu pukul. 10.30 WITA dan hari kamis pukul 10.30. Kemudian penelitian melakukan penelitian sebagai peneliti selama 3 minggu dengan jadwal yang telah ditentukan.Observasi dan penyebaran angket ini dilakukan 1 kali pertemuan, pertemuan dilaksanakan pada hari rabu, 14 Oktober 2015 jam ke 3 dan 5 di kelas $\mathrm{Va}$ dan $\mathrm{Vb}$. Angket dalam penelitian ini terdiri dari 1 bagian yaitu angket tentang metodeinkuiri berjumlah 15 item pernyataan. Sebelum angket dibagikan kepada responden/subjek penelitian, peneliti terlebih dahulu menjelaskan maksud dan tata cara pengisian dari masing-masing angket tersebut. Penyebaran angket tersebut dilakukan setelah proses pembelajaran berlangsung, angket tersebut ditarik pada hari itu juga dengan dibantu oleh guru mata pelajaran IPA kelas Va dan $\mathrm{Vb}$, siswa-siswi itu sendiri.

Berdasarkan data hasil skor angket metode inkuiri. Kelas Va dan Vb di SD Negeri 3 Dompu Tahun pembelajaraan 2015/2016. Sebagai mana pada lampiran VI halaman 66.

Bahwa hasil angket/quisioner yang telah dibagikan kepada responden/siswa sebanyak 54 orang pada kelas $\mathrm{Va}$ dan $\mathrm{Vb}$ SD Negeri 3 Dompu dapat peneliti menyimpulkan hasil angket/quisioner atau jawaban yang dicentang $(\sqrt{ })$ oleh responden/siswa SD Negeri 3 Dompu yaitu angket/quisioner untuk jumlah metode inkuiri adalah 2677 dengan nilai tertinggi 55 dan nilai terendahnya adalah 40. Ratarata dari nilai metode inkuiri adalah 49.5741

\section{1) Data Hasil Perhitungan Hasil Belajar}

Pada penelitian ini menggunakan teknik tes digunakan untuk mendapatkan nilai tes mata pelajaran ilmu pengetahuan alam siswa kelas Va dan Vb pada materi tumbuhan hijau setelah materi yang dipelajari selesai, dan soal tes ini terdiri dari 20 item soal dengan pertanyaan yang bervarias berikut ini adalah data hasil belajar siswa kelas $\mathrm{Va}$ dan $\mathrm{Vb}$ :

Berdasarkan Hasil Analisis Tes Siswa Kelas Va dan Vb SD Negeri 3 Dompu sebagai mana pada lampiran $\mathrm{V}$ halaman 62.

\section{2) Analisis Data Regresi dan Persamaan Regresi}

Menurut Ustman (2013: 50) Untuk menentukan persamaan regresi, perlu dilakukan pengujian sebagai berikut :
a. Uji Normalitas Regresi
b. Uji Multikolinieritas
c. Uji Heteroskedastisitas 
d. Uji Autokorelas

Tabel 2. Hasil Uji multikolinieritas

\section{Coefficients $^{\mathrm{a}}$}

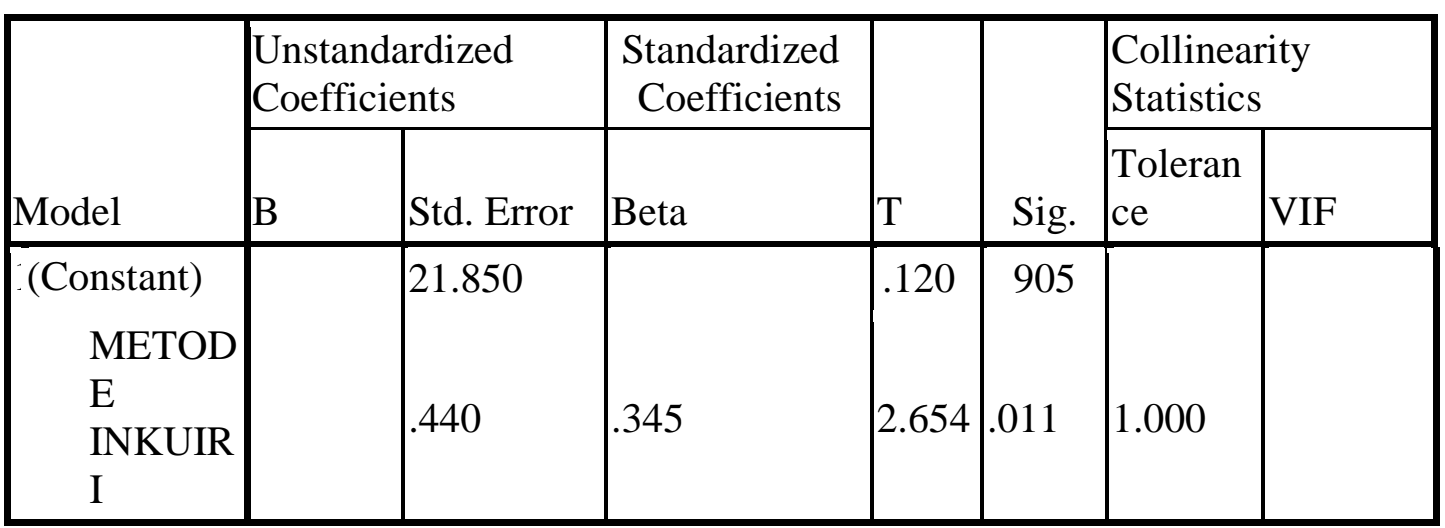

a. Dependent Variable:Hasil Belajar

Dari tabel dapat dilihat nilai VIF $>10$ dan nilai tolerance $<0,10$ maka tidak terjadi gejala Multikolinieritas.

\section{1) Deskripsi Data hasil Uji Heteroskedastisitas}

Uji heteroskedastisitas bertujuan untuk menguji apakah dalam model regresi terjadi ketidaksamaan variance dari residual satu pengamataan ke pengamatan yang lain tetap, atau disebut homoskedastisitas. Model regresi yang baik adalah yang homoskedastisitas, tidak heteroskedastisitas.

Salah satu cara untuk mendeteksi heteroskedastisitas adalah dengan melihat grafik scatter plot antara lain prediksi variable terikat (ZPREID) dengan residualnya (SRESID). Jika ada titik pola tertentu yang teratur (bergelombang, melebar kemudian menyempit) maka mengindikasikan telah terjadi heteroskedastisitas.Jika tidak ada pola yang jelas, serta titik-titik menyebar diatas dan dibawah angka 0 pada sumbu Y, maka tidak terjadi heteroskedastisitas. Berikut langkah-langkah pengujiannya: a sampai dengan c sama dengan uji normalitas.

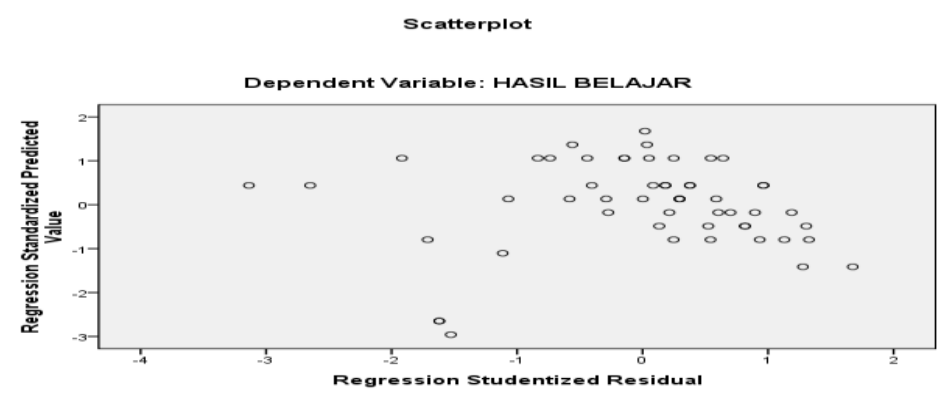

Gambar 1. Hasil Uji Heteroskedastisitas

Dilihat dari gambar tidak ada pola yang jelas, serta titik-titik menyebar diatas dan dibawah angka 0 pada sumbu Y, maka tidak terjadi heteroskedastisitas. 


\section{2) Deskripsi Data hasil Uji Autokorelasi}

Uji Autokorelasi bertujuan menguji apakah dalam model regresi linier ada korelasi antara kesalahan pengganggu pada periode t-1.Persyaratan yang harus dipenuhi adalah tidak adanya autokorelasi dalam model regresi, dengan ketentuan.

a) Jika d lebih kecil dari dl atau lebih besar dari (4-dl) maka hipotesis nol ditolak, atau terdapat autokorelasi .

b) Jika d terletak diantara du dan dl (4-du) maka hipotesis nol diterima,berarti tidak ada autokorelasi.

c) Jika d terletak antara dl dan du atau antara (4-du) dan (4-dl) maka tidak menghasilkan kesimpulan (ragu-ragu).

Tabel 3. Model Summary

\begin{tabular}{|l|l|l|l|l|l|}
\hline Model & $\mathrm{R}$ & $\mathrm{R}$ Square & $\begin{array}{l}\text { Adjusted R } \\
\text { Square }\end{array}$ & $\begin{array}{l}\text { Std. Error of the } \\
\text { Estimate }\end{array}$ & $\begin{array}{l}\text { Durbin- } \\
\text { Watson }\end{array}$ \\
\hline 1 & & & & & \\
& $.345^{\mathrm{a}}$ & .119 & .102 & 10.36358 & 1.113 \\
\hline
\end{tabular}

a. Predictors: (Constant), METODE INKUIRI

b. Dependent Variable: HASIL

BELAJAR

Dari tabel di atas uji gejala autokorelasi dilakukan dengan melihat hasil Durbin-Watson yang nilainya sebesar 1.113 Dengan signifikan 0,05 $\mathrm{N}$ (observasi)= 54 dan $\mathrm{k}$ (Variabel Independen $)=1(\mathrm{~K}=1)$ dan di peroleh nilai $\mathrm{dl}=1.5230$ sementara nilai du $=1.5983$. oleh karena $\mathrm{D}-\mathrm{W} 1.113$ berada di bawah $\mathrm{dl}=1.5230$ maka dapat disimpulkan terdapat autokorelasi positif, hal ini berarti model regresi yang dihasilkan pada penelitian ini bebas dari autokorelasi.

\section{3) Langkah Kerja Spss Untuk Menentukan Persamaan Regresinya}

Berikut adalah hasil output SPSS untuk menentukan persamaan regresinya:

Tabel 4. Output Spss Descriptive Statistics

Descriptive Statistics

\begin{tabular}{|c|l|l|l|}
\hline & Mean & Std. Deviation & $\mathrm{N}$ \\
\hline $\begin{array}{c}\text { Metode Inkuiri } \\
\text { Hasil Belajar }\end{array}$ & 49.5741 & 3.23659 & 54 \\
& 60.4815 & 10.93849 & 54 \\
\hline
\end{tabular}

Tabel 5. Correlations

\begin{tabular}{|ll|l|l|}
\hline & & METODE INKUIRI & HASIL BELAJAR \\
\hline Metode & Pearson Correlation & 1 & $.345^{*}$ \\
inkuiri & Sig. (2-Tailed) & & .011 \\
& $\mathrm{~N}$ & 54 & 54 \\
\hline
\end{tabular}

@ 2021 JagoMipa (https://bimaberilmu.com/jurnal/index.php/jagomipa) 


\begin{tabular}{|l|l|l|}
\hline Hasil Pearson Correlation & $.345^{*}$ & 1 \\
belajar Sig. (2-tailed) & .011 & \\
$\mathrm{~N}$ & 54 & 54 \\
\hline
\end{tabular}

*. Correlation is significant at the 0.05 level (2-tailed).

Rata-rata metode inkuiri adalah49.5741 dan hasil belajar siswa adalah 60.4815 . Korelasi antara hasil belajar siswa dan metode inkuiri ternyata kurang siqnifikan $(>0,05)$ jadi korelasi antara kedua variabel rendah yaitu 0,011 .

Standard error estimasi sebesar 10.93849 bandingkan dengan standard deviasi hasil belajar yaitu 10.36368pada tabel output pertama. Karena Standard error estimasi lebih besar dari standard deviasi, maka model regresi ini tidak bertindak sebagai prediktor untuk hasil belajar siswa.

Tabel 6. ANOVA ${ }^{\mathrm{b}}$

\begin{tabular}{|lc|l|l|l|l|l|}
\hline \multicolumn{1}{|l|}{} & & $\begin{array}{l}\text { Sum of } \\
\text { Model }\end{array}$ & & & & \\
\hline 1 & Squares & df & Mean Square & F & Sig. \\
\hline & Regression & 756.479 & 1 & 756.479 & 7.043 & $.011^{\mathrm{a}}$ \\
& Residual & 5585.002 & 52 & 107.404 & & \\
& Total & 6341.481 & 53 & & & \\
\hline
\end{tabular}

Tabel 7. Coefficients ${ }^{\mathrm{a}}$

\begin{tabular}{|c|c|c|c|c|c|c|c|}
\hline \multirow[b]{2}{*}{ Model } & \multicolumn{2}{|c|}{$\begin{array}{l}\text { Unstandardized } \\
\text { Coefficients }\end{array}$} & \multirow{2}{*}{ 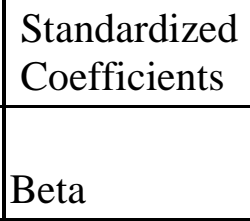 } & \multirow[b]{2}{*}{$\mathbf{T}$} & \multirow[b]{2}{*}{ Sig. } & \multicolumn{2}{|c|}{$\begin{array}{l}\text { Collinearity } \\
\text { Statistics }\end{array}$} \\
\hline & B & $\begin{array}{l}\text { Std. } \\
\text { Error }\end{array}$ & & & & $\begin{array}{c}\text { Toleran } \\
\text { ce }\end{array}$ & VIF \\
\hline (Constant) & 2.615 & 21.850 & & .120 & .905 & & \\
\hline $\begin{array}{l}\text { Metode } \\
\text { Inkuiri }\end{array}$ & 1.167 & .440 & .345 & 2.654 & .011 & 1.000 & 1.000 \\
\hline
\end{tabular}

a. Dependent Variable: HASIL BELAJAR

a. Predictors: (Constant), METODE

INKUIRI

b. Dependent Variable: HASIL

BELAJAR

Dari tabel Anova, terlihat bahwa $F_{\text {hitung }}$ yang diperoleh adalah 1 dengan signifikansi $0.011^{\mathrm{a}}<0,05$ yang artinya model regresi tidak dapat dipakai untuk memprediksi variabel hasil belajar.

Tabel diatas menunjukan persamaan regresi $Y=2.615+1.167 x$. Maknanya jika variabel $\mathrm{X}$ adalah 0 maka nilai variabel $\mathrm{Y}$ adalah 2.615 dan jika variabel $\mathrm{X}$ di naikkan satu satuan maka variabel Y akan menjadi 1.167. Untuk menguji signifikansi konstanta kita dapat melihat hasil dari uji t. Terlihat bahwa metode inkuiri adalah sebesar $0,011<0,05$ yang artinya bahwa metode inkuiri tidak berpengaruh secara signifikandengan $\mathrm{R}^{2}=0,011 \times 100 \%=1,1 \%$ terhadap hasil belajar siswa dan yang paling besar signifikan besarnya adalah sebanyak $99,9 \%$ oleh faktor lain. 


\section{PEMBAHASAN}

\section{Metode Inkuiri}

Menurut Sumantri M. Dan Permana (2000:142) adalah cara penyajian pelajaran dengan memberi kesempatan kepada peserta didik untuk menemukan informasi dengan atau tanpa bantuan guru. Metode Inkuiri memungkinkan para peserta didik menemukan sendiri informasi-informasi yang diperlukan untuk mencapai tujuan belajarnya, karena Metode Inkuiri melibatkan peserta didik dalam proses-proses mental untuk penemua suatu konsep berdasarkan informasi-informasi yang diberikan guru.

Untuk memperoleh data tentang penerapan metode inkuiri peneliti menggunakan metode angket/quisioner. Angket/quisioner adalah sejumlah pertanyaan tertulis yang digunakan untuk memperoleh informasi dari responden dalam arti laporan tentang pribadinya atau hal-hal yang diketahui (Mardalis dalam Arikunto, 2002: 128). Instrumen yang digunakan yaitu angket tertutup. Muatan angket berisi pertanyaan-pertanyaan dan pilihan jawaban yang ditujukan kepada responden yang telah disediakan oleh penulis berupa lembar angket/questioner untuk memperoleh respon positif dan negatif tentang pengaruh metode inkuiri sebagai terlampir. Angket ini diberikan pada siswa untuk melengkapi data yang diperlukan.

Angket diberikan kepada siswa kelas Va dan V-b dengan jumlah 15 pertanyaan. Angket ini disebarkan pada akhir pembelajaran, angket diberikan untuk melihat jawaban-jawaban dari siswa terhadap pengaruh metode inkuiri terhadap hasil belajar di SD Negeri 3 Dompu tahun pembelajaran 2015/2016.

Pada penelitian ini, penulis menggunakan skala Likert.Menurut Sugiyono (2014: 93) skala likert digunakan untuk mengukur sikap, pendapat dan persepsi seseorang, kelompok orang tentang fenomena sosial. Pilihan terhadap masingmasing jawaban untuk tanggapan responden atas penerapan metode inkuiri $(\mathrm{X})$ dan hasil belajar (Y).

\section{Hasil Belajar}

Arikunto (1990:133) mengatakan bahwa hasil belajar adalah hasil akhir setelah mengalami proses belajar, perubahan itu tampak dalam perbuatan yang dapat diaamati,dan dapat diukur". Nasution (1995 : 25) mengemukakan bahwa hasil adalah suatu perubahan pada diri individu. Perubahan yang dimaksud tidak halnya perubahan pengetahuan, tetapi juga meliputi perubahan kecakapan, sikap, pengertian, dan penghargaan diri pada individu tersebut.

Dari beberapa pendapat di atas, maka dapat disimpulkan bahwa hasil belajar adalah hasil yang dicapai oleh seseorang dalam usaha belajar menurut kemampuan yang ditandai dengan perkembangan serta perubahan tingkah laku pada diri seseorang yang diperlukan dari belajar dengan waktu tertentu sesuai dengan bobot yang dicapainya. Untuk mengumpulkan data tentang hasil belajar peneliti menggunakan metode tes yaitu dengan membagikan soal tes setelah materi tumbuhan hijau telah dipelajari. Soal tes diberikan kepada siswa kelas $\mathrm{Va}$ dan $\mathrm{Vb}$ dengan jumlah 20 pertanyaan.Tes ini disebarkan pada akhir pembelajaran, tes diberikan untuk melihat hasil belajar di SDNegeri 3 Dompu tahun pembelajaran 2015/2016.

Data hasil belajar siswa melalu teknik tes bahwa didapatkan jumlahnya adalah 2677 dari 54 siswa dengan nilai tertinggi 72 dan nilai terendahnya adalah 30 . 
Tabel 8. Distribusi nilai

\begin{tabular}{|l|l|l|l|}
\hline Kriteria & Jumlah & Jumlah & $\%$ \\
\hline Nilai tertinggi & $60-80$ & 38 & $30 \%$ \\
Nilai sedang & $40-59$ & 11 & $10 \%$ \\
Nilai & $<39$ & 5 & $5 \%$ \\
& & & $5 \%$ \\
\hline & & 54 & \\
\hline
\end{tabular}

\section{Pengaruh metode inkuiri terhadap hasil belajar}

Menurut (Ustman, 2013: 50) Sebelum menentukan persamaan regresinya, dilakukan uji normalitas regresi, uji multikolonieritas, uji heteroskedastisitas dan uji autokorelasi.

Berdasarkan hasil analisis yang dilakukan dengan mengggunakan aplikasi SPSS 16.0 menunjukkan bahwatidak terjadi pengaruh yang signifikan antara penerapan metode inkuiri terhadap hasil belajar siswa pada SDNegeri 3 Dompu tahun pembelajaran 2015/2016dengan $\mathrm{R}^{2}=0,011 \times 100 \%=1,1 \%$ sedangkan $99,9 \%$ dipengaruhi oleh faktor lain yaitu pada ketrampilan bertanya, keterampilan memberi penguatan, keterampilan menjelaskan, keterampilan mengadakan, metode inkuiri. Dalam pelaksanaan pembelajaran guru membimbing siswa agar aktif mengembangkan kegiatan belajar yang mengarah pada pencapain tujuan. Yang perlu diperhatikan disini adalah siswa harus aktif mengembangkan kemampuannya untuk memecahkan masalah.Berdasarkan data ini, dapat disimpulkan bahwa jika metode inkuiri lebih baik, maka bisa diprediksikan hasil belajar siswa juga.

Akan lebih baik. Kategori ini mengindikasikan bahwa guru IPA kelas V belum menunjukkan keberhasilannya dalam mengantarkan siswanya untuk berprestasi. Hanya saja masih harus diupayakan lebih keras lagi melalui langkah-langkah kreatif dan inovatif yang mampu meningkatkan hasil belajar siswa berdasarkan nilai-nilai yang dimiliki oleh sekolah dasar, terutama dalam hal penerapan metode inkuiri yang akan menumbuhkan semangat penghayatan nilai-nilai dan sikap-sikap positif lainnya.

Berdasarkan hasil analisis inferensial menggunakan teknik regresi linier skor keterampilan mengelola kelas $r x y=0.120$ dengan taraf signifikansi $5 \%$, hal ini menunjukkan bahwa penggunaan metode inkuiri tidak mempunyai pengaruh terhadap hasil belajar siswa. Dengan demikian maka hipotesis yang diajukan pada penelitian ini yaitu diduga ada pengaruh metode inkuiri terhadap hasil belajar siswa peneliti menyatakan dengan tegas DITOLAK hipotesisnya.Pengaruh metode inkuiri terhadap hasilbelajar siswa mempunyai signifikan konstanta kita dapat melihat hasil dari uji t pada tabel. Terlihat bahwa metode inkuiri adalah sebesar 0,011>0,05 yang artinya bahwa metode inkuiri tidak berpengaruh secara signifikandengan $R^{2}=0,011 \mathrm{x}$ $100 \%=1,1 \%$ terhadap hasil belajar siswa dan yang paling besar signifikan besarnya adalah sebanyak $99,9 \%$ oleh factor lain. Dengan hasil persamaan regresinya adalah, $Y=2.615+1.167 x$. maknanya jika variabel $\mathrm{X}$ adalah 0 maka nilai variabel $\mathrm{Y}$ adalah 2.615 dan jika variabel $\mathrm{X}$ di naikkan satu satuan maka variabel $\mathrm{Y}$ akan menjadi 1.167 . 


\section{KESIMPULAN}

Dari hasil analisis data yang telah dilakukan dapat disimpulkan bahwa: ada pengaruh metode inkuiri terhadap hasil belajar ilmu pengetahuan alam siswa kelas V di SD Negeri 3 Dompu tahun pembelajaran 2020/2021. Hal tersebut sesuai prosedur pengujian yang telah dilakukan bahwa.Pengaruh metode inkuiri terhadap hasil belajar siswa mempunyai signifikan konstanta kita dapat melihat hasil dari uji t pada tabel. Terlihat bahwa metode inkuiri adalah sebesar $0,011>0,05$ yang artinya bahwa metode inkuiri berpengaruh secara signifikan dengan $\mathrm{R}^{2}=0,011$ x $100 \%=1,1 \%$ terhadap hasil belajar siswa dan yang paling besar signifikan besarnya adalah sebanyak 99,9\% oleh faktor lain. Semakin baik metode inkuiri semakin baik pula hasil belajar siswa.

\section{DAFTAR PUSTAKA}

Anita, Sri W, (2001). Metode Belajar Mengajar.Bandung: Alfabeta.

Arikunto, S. (2002). Prosedur Penelitian Suatu Pendekatan Praktis. Jakarta: Rineka Cipta.

Dimyati dan Mudjiono. (2006). Belajar dan Pembelajaran. Jakarta: Rineka Cipta.

Djamarah, (2002). Prestasi Belajar dan Kompetensi siswa. Surabaya: Usaha Nasional.

Hamalik, Oemar. (2001). BelajarMengajar. Jakarta: Bumi Aksara.

Hamruni. (2012). Strategi Pembelajaran. Yogyakarta: Insan Madani.

Ida. (2005). Metode Pembelajaran. Yogyakarta: Yappindis.

Mulyasa, E. (2006). Kurikulum Berbasis Kompetensi.Bandung: Remaja Rosda Karya.

Sagala, Syaiful. (2003). Metode Belajar Mengajar. Bandung: Alfabeta.

Sanjaya, Wina. (2012). Strategi Pembelajaran Berorientasi Standar ProsesPendidikan. Jakarta: Kencana.

Sudrajat, Akhmad. (2011). Pembelajaran Inkuiri. (Online) (https://akhmadsudrajat.wordpress.com/2011/09/12/pembelajaran-inkuiri/, diakses pada tanggal 14 November 2014).

Trianto. (2010). Model Pembelajaran Terpadu. Jakarta: PT. Bumi Aksara.

Usman, Moh. Uzer. (2013). Menjadi Guru Profesional. Bandung: Remaja Rosdakarya.

Yulianto, Toto. (2013). Metode Inkuiri. (Online), (http://totoyulianto.wordpress.com/2013/03/02/metode-inkuiri-imetodepembelajaran/, diakses pada tanggal 14November 2014). 